\title{
Editorial
}

\section{Aplicabilidade de teorias de enfermagem na prática cotidiana do trabalho}

Neste século da informação e disseminação do conhecimento, pesquisadores de enfermagem vêm sendo pressionados a produzir artigos e publicá-los em periódicos altamente qualificados. Aqui se reporta, particularmente, à aplicabilidade de teorias aos saberes dessa profissão relacionada aos cuidados desenvolvidos com os clientes, bem como seus efeitos na promoção, prevenção e recuperação da saúde/bem-estar.

Isso porque ainda persiste entre esses pesquisadores a percepção de ser necessário comprovar a cientificidade da enfermagem brasileira. Pensamos que o fato de se trabalhar em equipe inter e multidisciplinar conduz à exigência de se destacar o conhecimento específico adquirido por enfermeiras (os) para cuidar de pessoas e a juventude dessa profissão, no contexto da cientificidade.

Considerando este século, sobreleva-se o acréscimo de novas teorias e uma das formas de desvelar essa cientificidade é aplicá-las no cotidiano das práticas do cuidar, educar e pesquisar. Nesse sentido, concordamos com Brookes ${ }^{1}$, quando afirma que, ao longo de 50 anos e por meio das teorias, tornou-se notável o crescimento e a expansão do conhecimento, da educação e da bibliografia de enfermagem.

Lendo o livro Nursing theorists and their works ${ }^{1}$, constatamos a pertinência da aplicabilidade do Tidal Model, teoria até então desconhecida no Brasil, criada por Phil Barker e centrada em saúde mental (SM)². Decidimos, então, aplicar este referencial em nossa pesquisa cujo foco é o cuidado de pessoas com sofrimento psíquico.

Filosoficamente, para Barker, a recuperação da SM diferencia-se do atual tratamento do transtorno mental. Numa visão específica de mundo, auxilia o entendimento do que é SM na perspectiva do cliente e de como ajudá-lo na sua recuperação, compreendendo a vida humana nas dimensões físicas, emocionais, intelectuais, sociais e espirituais. Dessa forma, profissional e cliente unem-se como membros de um corpo de balé. Isso significa que, nos encontros genuínos, passam a se cuidar e não se deixar cuidar por outra pessoa.

Assim, consultamos o autor sobre a possibilidade de aplicar sua teoria na elaboração de um protocolo (tecnologia) de cuidar adequado à realidade brasileira. Satisfeito com a divulgação de sua teoria no Brasil, já iniciada na publicação do artigo Perspectiva estética e sociopoética ao cuidar de pessoas com sofrimento psíquico: apropriação do Tidal Model $^{3}$, encaminhou-nos comunicado, enfatizando tratar-se da primeira publicação no Brasil sobre o Tidal Model. Como consequência, pesquisadores de outros países, em especial da Mälardalen University/Suécia, demonstraram interesse em introduzir este modelo no ensino de saúde mental.

A Revista Enfermagem Uerj orgulha-se de ter sido o veículo desta publicação pioneira, cumprindo, assim, seu papel na divulgação da inovação e do avanço no conhecimento.

Iraci dos Santos

Editora Associada

Leandro Andrade da Silva

Doutorando do PPGENF/UERJ

\section{Referências}

1.Brookes N. The Tidal Model in the mental health recuperation. $7^{\text {th }}$ ed. In: Alligood MR, Tomey AM. Nursing theorists and their works. New York (EUA): Elsevier; 2011.

2.Barker PJ, Buchanan-Barker. Mental health nursing and the politics of recovery: a global reflection. Archives of Psychiatric Nursing. 2011; 25:350-8.

3.Santos I dos, Silva LA, Clos AC, Nascimento AV. Perspectiva estética e sociopoética ao cuidar de pessoas com sofrimento psíquico: apropriação do Tidal Model. Rev enferm UERJ. 2014; 22:815-20. 
